\title{
A bibliography of Susan Reynolds's work (to 1999)
}

\author{
compiled by Pamela Taylor
}

1955

'Leicestershire: Table of Population, 1801-1951', in The Victoria History of the Counties of England. A History of the County of Leicester, 3, London, Oxford University Press for the Institute of Historical Research, pp. 176-217.

\section{6}

'Pleas in the Liberty of the Abbot of Battle at Bromham', in N. J. Williams (ed.), Collectanea, Wiltshire Archaeological and Natural History Society Records Branch, 12, pp. 129-41.

Sections on 'Charities' in all twenty-six parishes in The Victoria History of the Counties of England. A History of the County of Essex, 4, London, Oxford University Press for the Institute of Historical Research.

1959

'The City of Cambridge: Schools', pp. 141-6; 'Almshouses', pp. 146-7; 'Other Charities', pp. 147-8, in The Victoria History of the Counties of England. A History of the County of Cambridge and the Isle of Ely, 3, London, Oxford University Press for the Institute of Historical Research.

\section{2}

Ed., The Victoria History of the Counties of England. A History of the County of Middlesex, 3, London, Oxford University Press for the Institute of Historical Research; author of contributory chapters: 'Staines', pp. 13-33; 'Stanwell', pp. 33-50; 'Teddington', pp. 66-82; 'Isleworth Hundred', pp. 83-4; 'Heston and Isleworth', pp. 85-139; 'Twickenham', pp. 139-66; 'Cowley', pp. 170-7; 'Hanwell', pp. 220-37; 'Harlington', pp. 258-75.

\section{4}

'The City of Birmingham: Manors', with L. F. Salzman, pp. 58-73; 'Agriculture', pp. 24651; 'Markets and Fairs', pp. 251-3; 'Roman Catholicism', pp. 397-411; 'Schools', pp. 501-49, in The Victoria History of the Counties of England. A History of the County 
of Warwick, 7, London, Oxford University Press for the Institute of Historical Research.

\section{5}

Ed., The Register of Roger Martival Bishop of Salisbury 1315-1330. Vol. Ill Royal Writs, Canterbury and York Society, 59.

\section{6}

Review of A. Fremantle and the editors of Time-Life Books, Age of Faith, in The Brown Book, Oxford, Lady Margaret Hall, p. 59.

\section{7}

Review of M. Aston, Thomas Arundel: A Study of Church Life in the Reign of Richard II, in The Brown Book, Oxford, Lady Margaret Hall, pp. 49-50.

\section{9}

'The forged charters of Barnstaple', English Historical Review, 84, pp. 699-720; reprinted in Ideas and Solidarities, 1995.

'Oxford Letter', in The Brown Book, Oxford, Lady Margaret Hall, pp. 3-6.

Review of M. Chibnall (ed.), The Ecclesiastical History of Ordericus Vitalis, vol. ii, in The Brown Book, Oxford, Lady Margaret Hall, pp. 51-2.

Review of W. George, Animals and Maps, in The Brown Book, Oxford, Lady Margaret Hall, pp. 54-5.

1970

'Oxford Letter', in The Brown Book, Oxford, Lady Margaret Hall, pp. 3-5.

Review of N. D. Hurnard, The King's Pardon for Homicide before AD 1307, in The Brown Book, Oxford, Lady Margaret Hall, pp. 50-1.

'Oxford Letter', in The Brown Book, Oxford, Lady Margaret Hall, pp. 4-7.

\section{2}

'The Rulers of London in the Twelfth Century', History, 57, pp. 337-57; reprinted in Ideas and Solidarities, 1995.

1973

'Henry I's Charter for London', Journal of Society of Archivists, 4, pp. 558-78; with C. N. L. Brooke and G. Keir. 
Review of H. M. Jewell, English Local Administration in the Middle Ages, in The Brown Book, Oxford, Lady Margaret Hall, pp. 62-3.

\section{5}

'The farm and taxes of London, 1154-1216', Guildhall Studies in London History, 1, pp. 211-28; reprinted in Ideas and Solidarities, 1995.

Review of K. M. Briggs, The Folklore of the Cotswolds, in The Brown Book, Oxford, Lady Margaret Hall, pp. 41-2.

1977

An Introduction to the History of English Medieval Towns, Oxford, Clarendon Press.

Review of G. Tindall, The Fields Beneath, in The Brown Book, Oxford, Lady Margaret Hall, pp. 53-4.

\section{0}

'Decline and decay in Late Medieval Towns: A look at some of the concepts and arguments', Urban History Yearbook, pp. 76-8; reprinted in reformatted version in Ideas and Solidarities, 1995, pp. 1-4.

\section{1}

'Eadric Silvaticus and the English Resistance', Bulletin of the Institute of Historical Research, 54, pp. 102-5; reprinted in Ideas and Solidarities, 1995.

'Law and Communities in Western Europe, c.900-1300', American Journal of Legal History, 25, pp. 205-24.

Review of G. U. S. Corbett (ed.), Ancient and Historical Monuments in the City of Salisbury, i, in English Historical Review, 96, pp. 842-4.

Review of M. Chibnall (ed.), The Ecclesiastical History of Ordericus Vitalis, I, in The Brown Book, Oxford, Lady Margaret Hall, pp. 38-9.

\section{2}

'Medieval Urban History and the History of Political Thought', Urban History Yearbook, pp. 14-23; reprinted in reformatted version in Ideas and Solidarities, 1995, pp. 1-13.

\section{3}

'1483: Gloucester and Town Government in the Middle Ages', in N. M. Herbert et al. (eds), The 1483 Gloucester Charter in History, Gloucester, Alan Sutton, pp. 40-51; reprinted in Ideas and Solidarities, 1995.

'Medieval origines gentium and the Community of the Realm', History, 68, pp. 375-90, reprinted in Ideas and Solidarities, 1995.

Obituary of Georgina Rosalie Galbraith (Cole-Baker) 1894-1982, in The Brown Book, Oxford, Lady Margaret Hall, pp. 39-40. 


\section{4}

Kingdoms and Communities in Western Europe, 900-1300; Oxford, Oxford University Press (2nd edn 1997).

Review of C. V. Wedgwood, The Spoils of Time: A Short History of the World, 1: From the Earliest Times to the Sixteenth Century, in The Brown Book, Oxford, Lady Margaret Hall, p. 44.

\section{5}

'What do we mean by "Anglo-Saxon" and "Anglo-Saxons"?', Journal of British Studies, 24, pp. 395-414; reprinted in Ideas and Solidarities, 1995.

'The Idea of the Corporation in Western Europe before 1300', in J. Guy (ed.), Law and Social Change in British History, London, Swift Printers for Royal Historical Society, pp. 27-33.

Review of J. A. Raftis, A Small Town in Late Medieval England: Godmanchester, 12781400, in English Historical Review, 100, pp. 168-9.

Review of A. R. Bridbury, Medieval English Clothmaking: An Economic Survey, in English Historical Review, 100, pp. 373-4.

\section{6}

'Chertsey, Surrey and Laleham, Middlesex' and 'Staines, Middlesex', in R. A. Skelton and P. D. A. Harvey (eds), Local Maps and Plans from Medieval England, Oxford, Clarendon Press, pp. 237-43, 245-50.

Review of The Survey of London, 41: Southern Kensington: Brompton, in English Historical Review, 101, pp. 758-9.

Review of The Victoria History of the Counties of England. The County of Somerset, 5, in History, 71, p. 114.

Review of U. Priestley (ed.), Men of Property - An Analysis of the Norwich Enrolled Deeds 1285-1311, in Journal of the Society of Archivists, 8, pp. 130-1.

Review of M. Chibnall, Anglo-Norman England, in The Brown Book, Oxford, Lady Margaret Hall, p. 44.

\section{7}

'Towns in Domesday Book', in J. C. Holt (ed.), Domesday Studies, pp. 295-309, Woodbridge, Boydell and Brewer for the Royal Historical Society; reprinted in Ideas and Solidarities, 1995.

'More about Feudalism', review article of T. J. Byres and H. Mukhia (eds), Feudalism and Non-European Societies, and E. Leach, S. N. Mukherjee and J. Ward (eds), Feudalism: Comparative Studies, in Peasant Studies, 14, pp. 250-9.

Obituary, with H. Pike and K. M. Lea, of Naomi Day Hurnard 1908-86, in The Brown Book, Oxford, Lady Margaret Hall, pp. 33-4.

Review of R. H. Britnell, Growth and Decline in Colchester, 1300-1525, in History, 72, p. 162.

Review of J. Haslam (ed.), Anglo-Saxon Towns in Southern England, in English Historical Review, 102, p. 462. 
Review of The Survey of London, 42: Southern Kensington: Kensington Square to Earls Court, in English Historical Review, 102, pp. 457-8.

\section{8}

Ed., with W. de Boer and G. MacNiocaill, Elenchus fontium historiae urbanae, II, 2; Leiden, E. J. Brill.

\section{9}

'Magna Carta 1297 and the legal use of literacy', Historical Research, 62, pp. 233-44; reprinted in Ideas and Solidarities, 1995.

'The History of Group Litigation', review article of S. Yeazell, From Medieval Group Litigation to the Modern Class Action, in UCLA Law Review, 37, pp. 421-32.

Review of R. Fuchs, Das Domesday Book und sein Umfeld: zur ethnischen und sozialen Aussagekraft einer Landesbeschreibung im England des 11. Jahrhunderts, in History, 74, p. 117.

Review of F. Opell, Stadt und Reich im 12. Jahrhundert (1125-1190), in English Historical Review, 104, p. 1009.

Review of R. D. Sack, Human Territoriality: Its Theory and History, in American Historical Review, 94, pp. 103-4.

Review of A. Hudson, The Premature Reformation, in The Brown Book, Oxford, Lady Margaret Hall, p. 48.

1990

Guest editor with B. Pulían, 'Towns and townspeople in Medieval and Renaissance Europe: Essays in Memory of J. K. Hyde', Bulletin of the John Rylands University Library of Manchester, 72: 3.

1991

'Bookland, Folkland and Fiefs', Anglo-Norman Studies, 14, pp. 211-27.

'Social Mentalities and the Case of Medieval Scepticism', Transactions of the Royal Historical Society, series 5, 41, pp. 21-41; reprinted in Ideas and Solidarities, 1995.

'Organizzazione dello spazio e del tempo nelle città medioevali inglesi', in P. Bonora (ed.), La città: dallo spazio storico allo spazio telematico, SEAT, Turin, pp. 97-102; revised English version, 'Space and Time in English Medieval Towns', in Ideas and Solidarities, 1995, pp. 1-7.

'Hypotheses rather than models: settlement and society in Medieval Europe. A Review Article': of C. J. Wickham, The Mountains and the City: The Tuscan Appenines in the Early Middle Ages, and A. Everitt, Continuity and Colonization: The Evolution of Kentish Settlement, in Comparative Studies in Society and History, 33, pp. 630-4.

Review of W. George and B. Yapp, The Naming of the Beasts, in The Brown Book, Oxford, Lady Margaret Hall, pp. 45-6. 
1992

'The writing of medieval Urban History in England', Theoretische Geschiednis/Historiography and Theory, 19, pp. 43-57; reprinted in Ideas and Solidarities, 1995.

Review of L. Genicot, Rural Communities in the Medieval West, in History, 249, pp. 104-5.

Review of M. Chibnall, The Empress Matilda, in The Brown Book, Oxford, Lady Margaret Hall, p. 39.

1993

Review of D. Abulafia, M. Franklin and M. Rubin (eds), Church and City AD 1000- 1500: Essays in Honour of Christopher Brooke, in Journal of Ecclesiastical History, 44, pp. 302-3.

Review of O. Brunner, Land and Lordship: Structures of Governance in Medieval Austria, in History, 78, pp. 294-5.

Review of H. Swanson, Medieval Artisans: An Urban Class in Late Medieval England, in American Historical Review, 98, pp. 1231-2.

\section{4}

'Christopher Elrington and the V.C.H.', in C. R. J. Currie and C. P. Lewis (eds), English County Histories: A Guide, Stroud, Alan Sutton, pp. 1-4. 2nd edn published 1997 as A Guide to English County Histories.

Fiefs and Vassals: The Medieval Evidence Reinterpreted, Oxford, Oxford University Press.

\section{5}

'English towns of the eleventh century in a European context', in P. Johanek (ed.), Die Stadt im 11. Jahrhundert, Münster, Institut für vergleichende Städtegeschichte an der Universität Münster, pp. 1-12; reprinted in Ideas and Solidarities, 1995.

Ideas and Solidarities of the Medieval Laity, Aldershot, Variorum.

Review of R. H. Hilton, English and French Towns in Feudal Society. A Comparative Study, in English Historical Review, 110, p. 691.

Review of P. Matarasso (ed.), The Cistercian World: Monastic Writings of the Twelfth Century, in The Brown Book, Oxford, Lady Margaret Hall, p. 83.

\section{6}

'English Towns', in A. Havercamp and H. Vollrath (eds), England and Germany in the High Middle Ages, London, German Historical Institute, and Oxford, Oxford University Press, pp. 271-82.

'The Authorship of the Fonthill Letter', with M. Boynton, in Anglo-Saxon England, 25, pp. 91-5.

1997

Kingdoms and Communities in Western Europe, 900-1300, 2nd edn, Oxford, Oxford University Press (1st edn 1984). 
'The historiography of the Medieval State', in M. Bentley (ed.), Companion to Historiography, London and New York, Routledge, pp. 117-38.

'La diversidad de enfoques y la problema de la especialización en historia medieval', review article of T. N. Bisson (ed.), Cultures of Power: Lordship, Status and Process in Twelfth-Century Europe, and W. Davies and P. Fouracre (eds), Property and Power in the Early Middle Ages, in Hispania: Revista Española de Historia, 57, pp. 329-37.

'Debate: Susan Reynolds to Johannes Fried', in Bulletin of the German Historical Institute, 19: 2, pp. 30-40.

Review of M. Bellomo, The Common Legal Past of Europe, AD 100-1800, in Speculum, 72, pp. 431-2.

\section{8}

'Nationalism and the idea of a nation: modern or old?' (translated into Japanese by $\mathrm{H}$. Tsurushima and M. Tanaguchi), Rekishi Hyoron, 584, pp. 5-22.

'Our forefathers? Tribes, Peoples and Nations in the historiography of the Age of Migration', in A. C. Murray (ed.), After Rome's Fall: Essays Presented to Walter Goffart, Toronto, University of Toronto Press, pp. 17-36.

Review of B. Pipon (ed.), Le Chartrier de l'Abbaye-aux Bois (1212)-1341, in French History, 12, pp. 93-4.

1999

'Carolingian elopements as a sidelight on counts and vassals', in B. Nagy and M. Sebök (eds), The Man of Many Devices, Who Wandered Full Many Ways: Festschrift in honour of Janos M. Bak, Budapest, Central European Press, pp. 340-6. 